\title{
The Development Model of Semar Counselling to Improve the Self-Esteem of Vocational Students with Psychological Distress
}

\author{
https://doi.org/10.3991/ijet.v14i10.10221 \\ Bakhrudin All Habsy ${ }^{(凶)}$, Nur Hidayah, Blasius Boli Lasan, Muslihati \\ State University of Malang, Malang, Indonesia \\ bakhrudin.habsy1601119@students.um.ac.id \\ Ahmad Fudholi \\ Universiti Kebangsaan Malaysia, Selangor, Malaysia.
}

\begin{abstract}
The development of the Semar counselling model is a new breakthrough as a pioneer of the counselling model of Indonesian cultural thinking, which was developed to improve the self-esteem of vocational students who experience psychological distress. The research procedure was adapted from the development research procedure of previous study, which consists of three stages: preparation stage, product preparation stage and test phase or product validation. An expert and a counsellor assessed the development of the Semar counselling model to improve the self-esteem of vocational students who experience psychological distress. They found that the acceptance criteria were met based on the Standards for Evaluation of Educational Programs, Projects and Materials. The result of a field trial using pretest and posttest control group design, Wilcoxon Signed Rank Test and two independent Mann-Whitney U Sample Tests showed that the Semar counselling model is more effective in improving the self-esteem of vocational students who experience psychological distress.
\end{abstract}

Keywords-Semar Counselling Model, Self-Esteem, Psychological Distress

\section{Introduction}

Vocational high school is one of the formal educational institutions in Indonesia after junior high school or Madarasah Tsanawiyah, which prepares students to work in certain fields [1]. Vocational high school has become the main program of the Indonesian government today, as proven by the increasing number of vocational high schools within five years, reaching a total of 3,000 and directly contributing to the growth of vocational students [2]. The Ministry of National Education of Indonesia seeks to strengthen the competence of vocational students in terms of knowledge, skills and attitudes as a whole, realised through the spirit of the 2013 curriculum as the first step to achieve Indonesia's Gold Generation Program in 2045. The Gold Generation Program is the figure of generation mandated in article 1 verse 1 number 
20 of the National Education System Act of 2003, namely, the generation that has the spiritual power, self-control, personality, intelligence, nobility and skills needed in the society, nation and state [1]. From the results of their research, Mahfud et al. [3] stated that school is the main source of psychological distress for students. This result is in line with Wulandari's [4] research, which states that a vocational student is faced with demands and expectations that are too large and cause burden and psychological distress for them. Various academic demands that bring psychological distress to students include family pressure, financial condition, competition with friends, different educational systems in junior high schools and vocational high schools and uncertain career and future success [5-7]. Lazarus [8] defines psychological distress as a psychological condition that arises when individuals do not have enough capacity to deal with environmental demands well. Psychological distress adversely affects and interferes with the individual's daily life [9]. The worst impact of psychological distress is experiencing depression, stress and anxiety [10-12]. The results of our literature study reveal that the level of psychological distress of vocational students is related to their self-esteem [13]. Self-esteem is the ability of individuals to evaluate or assess their self-worth, which leads to beliefs and mindsets that increase feelings of worth and dignity as individuals [14].

Self-esteem is an important construction that correlates with psychological distress, academic achievement, social relationships and pathological problems in children and adolescents [15]. A person's self-esteem may be dependent upon adaptive behavior, the quality of life, relationships with friends, psychological adjustment, school performance, motivation, and success in life [16]. A study conducted by Ismail et al. [17] suggests that high self-esteem has a relationship with the academic adjustment and psychological distress of students in general. Students who have low self-esteem will not succeed in performing tasks and responsibilities at school [18]. Thus, one of the factors that affect the psychological distress experienced by vocational high school students is low self-esteem. This statement was reinforced by Coopersmith [19], who states that adolescents with low self-esteem, lack of self-confidence and inability to assess their inner competencies feel alienated by the belief that they are unloved, too weak to admit deficiencies, sensitive to criticism, immersed in personal problems and escaping from social interaction.

Self-esteem can be concluded to be a personal evaluation of individual self-worth. For some teenagers who are in vocational high school, uncomfortable feelings caused by low self-esteem can develop into behavioural problems, such as seeking recognition and attention from classmates and the surrounding environment by making noise in the classroom, ignoring the teacher's instruction and neglecting tasks. Teenagers who have high self-esteem can understand and accept their selves more positively, remain optimistic despite their shortcomings, attempt to correct deficiencies through positive actions and tolerate failure well. McKay \& Fanning [20] presented the idea that self-assessment is influenced by the individual's interpretation of external circumstances and subsequent thoughts. Thus, the self-esteem of vocational high school students who experience psychological distress can be influenced by changing the individual's thinking and interpretation of external circumstances. 
The various phenomena and research results discussed above presents a problem as vocational high school students become the hope and foundation of leading the nation in the future. Students who are capable of handling various problems positively will act without harming themselves and the environment; however, those who look at various problems negatively will interpret themselves as meaningless or unworthy in the presence of others, thus reducing their self-esteem.

Based on the preliminary study conducted by the counsellor of a vocational high school in Mojokerto Regency, which was incorporated in the Counselling Teacher Guidance and Counselling Vocational High School, no special counselling services have been offered related to the problem of self-esteem of vocational high school students who experience psychological distress. Furthermore, the introduction of a self-esteem inventory to students in one vocational school in Mojokerto District shows that students who have low self-esteem in relation to academic achievement tend to experience psychological distress such as depression and anxiety when facing lessons, presenting in class and expressing their opinion during discussions. They also showed a lack of confidence and felt that they do not have enough capacity to face academic demands well. Based on the research carried out by Whiston et al. [21], they argued that the implementation of individual or group counselling can assist students in improving academic achievement, social skills, self-esteem, self-concept and some positive behaviours in school. However, according to [22], counsellors' understanding of the nature of human beings is crucial in the implementation of counselling because it is related to the counselling purposes, counsellor's roles and functions, counsellee and counsellor relationship, counselling procedures and techniques and ethical issues. This statement was confirmed by Dahlan [23], who suggested that religious and cultural values can be the foundation for formulating alternative guidance and counselling in the globalisation era. Similarly, Hidayah et al. [24] study states that the need for counselling has local cultural value.

Habsy et al. [25] indicated that the implementation of counselling services in Indonesia is oriented to the counselling from Western countries; that is, matters pertaining to good counselling techniques, procedures and stages are adopted from counselling from the West. In terms of development in the paradigm of counselling, there has been a shift so that thinking concerning the typical indigenous counselling of Indonesia has started to develop. Such development was initiated by Prayitno [26], who wrote Pancawaskita Counselling by integrating the five factors that influence an individual:

- Pancasila

- Liharid

- Pancadaya

- Masidu

- Likuladu.

Through the current research, a genuine Javanese cultural counselling model was developed which uses a puppet to characterise sifat lan solah bawane manungso or human nature and behaviour. Puppet or wewayangin ngurip is the shadow of human life that clearly depicts the concept of sangkan paraning dumadi, which means that 
man comes from God and will return to Him. Puppet is part of the cultural heritage of Indonesian ancestors, especially in Java, which contains excellent moral messages for life, including good values and the value of heroism to be exemplary [27].

The presence of Semar in the art of puppetry is a very popular figure in the Javanese community with a series of noble values. The Javanese are fascinated by Semar; this shadow is considered as a shadow (fantasy) of the ancestors of Java [28]. The idea is reinforced by Suseno [29], who claims that Semar is the most beloved wayang figure by the Javanese society. When he appears in front of the puppet show, he is greeted by a wave of audience sympathy and makes the audience feel that they under the aegis of Semar. Semar's role in puppetry was created by Javanese poets to convey the virtues of life and noble teachings contained in Javanese fibres [30-33].

The development of the Semar counselling model is a form of research dissemination conducted by researchers in 2017 through hermeneutic studies. This resulted in the construction of a systematised Semar counselling using the Gerald Corey framework, which includes

- Human nature

- Healthy and problematic person

- Counselling purposes

- Counselling relationships

- Counselling techniques

- Counselling stages [34]

For Semar's dominant theoretical framework (and road map), coherence leads to a flow of cognitive-behavioural approach [35].

\section{$2 \quad$ Method}

The following is a brief explanation of Semar counselling that adopts the Gerald Corey framework and the road maps of cognitive-behavioural approach. Firstly, the framework states that human nature consists of four components:

- Pancadriya or implementing instrument located in the eyes, ears, tongue, mouth and body

- Cognitive, which has the most dominant role among other personality structures, is used to cultivate or dispense the stimulus from the implementer/pancadriya

- Roso/Feeling has the second major role after cognitive; it is interpreted as a selfwhisper or an internalisation process that allows a person to dialogue internally with himself

- Action is used to realise the stimulus received by the pancadriya or implementing tools that have been processed by the mind and roso/feeling. Secondly, humans are made up of inner and outer parts

The inner part is the spirit, the soul called the gedhe universe (the place of thinking), while the outer part of the human body is his lust and the spiritual powers called 
the little universe. If he controls jagad cilik, he becomes ksatriya pinandita (hero who doubles as a priest; he cannot control the jagad cilik or the little universe if he cannot control jagad cilik and he will become a giant full of lust. Thirdly, the purpose of counselling is to assist the human being to be a person who has strong independence, power of roso/feeling and cognitive, ability to explore the truth, ability to cultivate the roso/feeling and ability to process cognitive and actions to escape from lust and bring truth and luck. Fourthly, in terms of counselling relationship, the counsellor acts as a servant of the counsellee in the implementation of counselling service who has the expertise of momong, momot and momong, as well as of copyright, intention and work. Counselling techniques stated in the framework are as follows:

- Dialogue of identity, which is the process of exploring one's potentials to solve problems by correcting mistakes

- Self-speech, which is the process of handling negative messages sent by developing healthier thinking

- Reconstruction of the cognitive, which involves looking for errors that cause selfcriticism, followed by rearranging the cognitive by denying the criticism. Lastly, the stages of counselling are the initial stage, the working stage and the final stage [35] The procedure is visualised and explained in Fig. 1.

\begin{tabular}{|c|c|c|}
\hline Initial Stage & Working Stage & Final Stage \\
\hline $\begin{array}{l}\text { Pancadriya or } \\
\text { implementer }\end{array}$ & $\begin{array}{c}\text { Treatment Giving and Applied } \\
\text { Technique }\end{array}$ & \multirow{5}{*}{$\begin{array}{l}\text { 1. Taking and giving Feed- } \\
\text { back } \\
\text { 2. Giving chances to pupils } \\
\text { to practice new attitudes } \\
\text { 3. Continuous learning } \\
\text { from specific planning and } \\
\text { development to apply } \\
\text { changes beyond counsel- } \\
\text { ling } \\
\text { 4. Preparing every member } \\
\text { to face the worse possibili- } \\
\text { ties } \\
5 \text {. Accompanying every } \\
\text { member in viewing group } \\
\text { experiences and under- } \\
\text { standing himself }\end{array}$} \\
\hline & Little Universe & \\
\hline Cognitive & $\begin{array}{l}\text { Big Universe (a true soul that always gives } \\
\text { guidance to the five senses of human) contains } \\
\text { man's character and the cognitive }\end{array}$ & \\
\hline Roso/Eeelino & $\begin{array}{l}\text { Giving treatment centered on the } \\
\text { mind that simultaneously gives panca- }\end{array}$ & \\
\hline Behaviour & $\begin{array}{l}\text { 1. Dialogue of identity } \\
\text { 2. Self-speech } \\
\text { 3. Reconstruction of the cognitive }\end{array}$ & \\
\hline & & \\
\hline
\end{tabular}

Fig. 1. Operational framework of the semar counselling model

Semar counselling model sees that low self-esteem starts when the counsellee begins to have a negative experience in life in the form of committing a mistake in the cognitive (jagad besar manusia), which then affects the pancadriya (jagad kecil manusia). The interaction between the cognitive (jagad besar manusia) and the pan- 
cadriya (jagad kecil manusia) affects the individual in processing the information provided by his social environment.

Intervention improves the self-esteem of vocational students who experience psychological distress by concentrating on the cognitive (jagad besar), which helps the counsellee establish the relationship between the cognitive (jagad besar) and the pancadriya (jagad kecil). The counsellor provides treatment on cognitive aspects, which are aspects that are simultaneous to one's central intentions. The intervention brings changes to the pancadriya (eyes, ears, tongue, ears and body). Based on the background presented above, the following conclusions are formed. Firstly, there is a need to develop the Semar counselling model and guide with multimedia design to stimulate the thoughts and actions clearly and in a way that can be understood by potential users, such as counsellors. Secondly, this development research will result in Semar's model and guidance counselling, which is largely theoretical, practical and feasible to use through accuracy, usefulness and implementation. The product of this research will be the Semar counselling model and guidance, which will be tested for effectiveness through product trial and experiment. Afterward, the Semar counselling model produced will be used to increase the self-esteem of vocational students who experience psychological distress. The development of the Semar counselling model adopted a research and development design model created by Borg \& Gall [36], Gall and Borg [37], Dwiyogo [38] and Sukmadinata [39], which is then modified into three steps:

- Preparatory stage, covering needs assessment, literature study, determination of development objectives and preparation of required materials

- Implementing stage, covering the draft of the Semar counselling model to increase the self-esteem of vocational students who experience psychological distress

- Testing stage or product validation, including trial, expert test, individual test (counsellor) and limited field test.

These steps are visualised and explained in Fig. 2, next page

Data analysis was carried out quantitatively through descriptive statistics. Quantitative data were derived from expert assessment scales developed from the theory of Standards for the Evaluation of Educational Programs, Projects and Materials. The scales consist of three aspects, namely, accuracy, usefulness and implementation [40].

Accuracy, usefulness and implementation each has 10 items having a gradation of 1 to 4 , with the minimum score obtained as $10 \times 1=10$, while the maximum score is $10 \times 4=40$. To determine the criteria of expert and counsellor assessment on the accuracy of the model, four criteria were developed as follows. Firstly, reach the maximum score of 40; secondly, reach the minimum score of 10; thirdly, calculate the difference between the maximum and minimum scores (i.e. $40-10=30$ ); and fourthly, determine the interval to get the four criteria by dividing the four maximum gain score difference by the minimum (i.e. 30/4 =7). The next step will be to determine the classification of these scores by intervals of 7 , as shown in Table 1. below Fig 2 
Stage I: Preparation

Analysis of the need and literature study

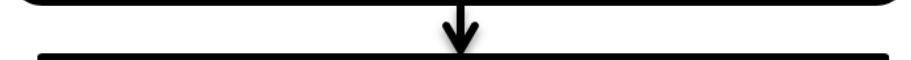

Stage II: Product arrangement

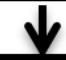

Stage III: Try out

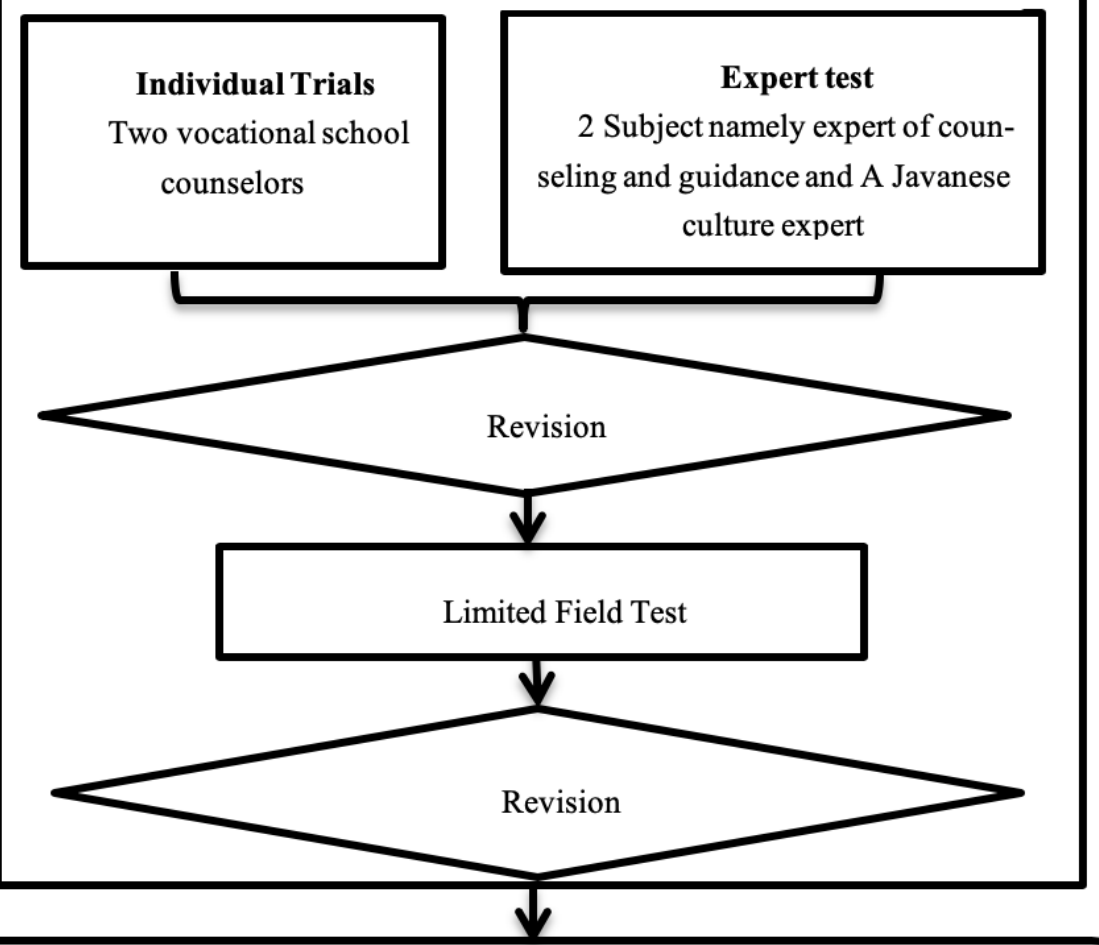

Final product

The development model of semar counseling to improve Self-esteem vocational students that have psychological distress

Fig. 2. Procedure for developing semar counselling models to improve the self-esteem of vocational high school students who experience psychological distress 
Table 1. Scoring criteria for accuracy, usability and performance

\begin{tabular}{|c|c|l|l|l|}
\hline No & Scoring & \multicolumn{1}{|c|}{ Accuracy Criteria } & Usefulness Criteria & Implementation Criteria \\
\hline 1 & $31-40$ & Very Accurate & Very Useful & Very Appropriate \\
\hline 2 & $24-30$ & Accurate & Useful & Appropriate \\
\hline 3 & $17-23$ & Less Accurate & Less Useful & Less Appropriate \\
\hline 4 & $10-16$ & Inaccurate & Not useful & Inappropriate \\
\hline
\end{tabular}

\section{Results and Discussion}

\subsection{Preparation stage results}

The results of the preparatory phase consist of data on the necessity assessment and results of the literature study. Necessity assessment was conducted at a vocational high school in Mojokerto Regency to decide whether or not the Semar counselling model can increase the self-esteem of vocational school students who experience psychological distress. Necessity assessment was done by distributing questionnaires to counsellors of a vocational high school in Mojokerto Regency included in the Counselling Teacher Guidance and Counselling. The result of the questionnaire dispersion show that $57.8 \%$ of the research subjects need Semar counselling model, while $42.2 \%$ require unique Indonesian cultural counselling. Literature study is conducted by examining the concepts or theoretical foundations that strengthen Semars counselling model. The theoretical foundation used in the development of the Semar counselling model is the puppet texts that contain the noble values of Semar.

\subsection{Results of product development stage}

The activity undertaken at this stage is the preparation of the product. Based on the necessity assessment, literature review and product testing or validation, including expert test, individual test (counsellor), limited field test (research subject) and revision of the guide, the final product was developed in the form of the Semar counselling model to improve the self-esteem of vocational high school students who experience psychological distress.

Semar counselling model consists of six main subjects:

- Human nature

- Healthy and problematic individuals

- Counselling purposes

- Counselling relationships

- Counselling techniques

- Counselling stages.

Semar Counselling Guide to the Improve Self-Esteem of Vocational High School Students Who Have Psychological Distress consists of three parts:

- Introduction 
- General guidance

- Procedure of Semar counselling model implementation.

\subsection{Expert test results}

The assessment results obtained from expert tests were used to revise the product and improve the design of the model before it was implemented on the prospective user. The expert test results can be seen by matching the total score obtained from the expert test with the criteria for assessing the accuracy, usability and implementation. Based on the quantitative results, experts on indigenous counselling gave a total score of 36 for accuracy with the category Very Accurate, whereas Javanese cultural experts gave a total score of 35 with the category Very Accurate. Scores from both experts showed that the Semar counselling model to improve the self-esteem of vocational high school students who experience psychological distress meets the criteria of accuracy. The results of expert judgment for accuracy can be seen in Table 2 .

The quantitative results revealed that the expert on indigenous counselling gave a total score of 40 for usability with the category Very Useful, whereas the expert on Javanese culture gave a total score of 38 with the category Very Useful. Scores from both experts indicate the Semar counselling model meets the usability criteria. Table 3 shows the expert test results for usability.

Table 2. Expert test results for accuracy

\begin{tabular}{|c|c|c|c|}
\hline No & Item Statement & $\begin{array}{c}\text { Javanese } \\
\text { Cultural } \\
\text { Expert }\end{array}$ & \begin{tabular}{|c|} 
Indigenous \\
Counselling \\
Expert
\end{tabular} \\
\hline 1 & $\begin{array}{l}\text { Accuracy of formulation of objectives of Semar Counselling Model to Improve } \\
\text { the Self-Esteem of Vocational High School Students Who Have Psychological } \\
\text { Distress }\end{array}$ & 2 & 4 \\
\hline 2 & $\begin{array}{l}\text { Appropriateness of the training activities of the Semar Counselling Model to } \\
\text { Improve the Self-Esteem of Vocational High School Students Who Experience } \\
\text { Psychological Distress }\end{array}$ & 3 & 4 \\
\hline 3 & $\begin{array}{l}\text { Accuracy of the stages of planned activities in the Semar Counselling Model to } \\
\text { Improve the Self-Esteem of Vocational High School Students Who Experience } \\
\text { Psychological Distress }\end{array}$ & 4 & 4 \\
\hline 4 & $\begin{array}{l}\text { Material Accuracy in the Semar Counselling Model to Improve the Self-Esteem } \\
\text { of Vocational High School Students Who Experience Psychological Distress }\end{array}$ & 4 & 4 \\
\hline 5 & $\begin{array}{l}\text { Accuracy of guidance for counsellors to facilitate the implementation of activi- } \\
\text { ties }\end{array}$ & 4 & 3 \\
\hline 6 & $\begin{array}{l}\text { The appropriateness of models and guides for students in the execution of } \\
\text { activities }\end{array}$ & 4 & 4 \\
\hline 7 & $\begin{array}{l}\text { The appropriateness of language use in the Semar Counselling Model to Im- } \\
\text { prove the Self-Esteem of Vocational High School Students Who Experience } \\
\text { Psychological Distress }\end{array}$ & 3 & 3 \\
\hline 8 & $\begin{array}{l}\text { Accuracy in the selection of media to develop the self-esteem of vocational high } \\
\text { school students who experience psychological distress }\end{array}$ & 3 & 4 \\
\hline 9 & The accuracy of time allocation of activities & 4 & 3 \\
\hline 10 & The accuracy of evaluation techniques & 4 & 3 \\
\hline & $\begin{array}{cc}\text { Total Score } \\
\end{array}$ & 35 & 36 \\
\hline
\end{tabular}


Table 3. Expert test results for usability

\begin{tabular}{|c|c|c|c|}
\hline No & Item Statement & \begin{tabular}{c|} 
Javanese \\
Cultural \\
Expert
\end{tabular} & $\begin{array}{c}\text { Indigenous } \\
\text { Counselling } \\
\text { Expert }\end{array}$ \\
\hline 1 & $\begin{array}{l}\text { The use of the Semar Counselling Model to Improve the Self-Esteem of } \\
\text { Vocational High School Students who Experience Psychological Distress }\end{array}$ & 4 & 4 \\
\hline 2 & $\begin{array}{l}\text { The use of the counselling model for the Semar counsellor to improve the } \\
\text { self-esteem of vocational high school students who have psychological } \\
\text { distress }\end{array}$ & 4 & 4 \\
\hline 3 & $\begin{array}{l}\text { The use of the counselling model allows the vocational high school student } \\
\text { with psychological distress to improve his/her self-esteem }\end{array}$ & 4 & 4 \\
\hline 4 & $\begin{array}{l}\text { The use of the counselling model material for the Semar counsellor to } \\
\text { improve the self-esteem of vocational high school students who have psy- } \\
\text { chological distress }\end{array}$ & 4 & 4 \\
\hline 5 & $\begin{array}{l}\text { The use of the counselling model activities for Semar counsellors to im- } \\
\text { prove the self-esteem of vocational high school students who have psycho- } \\
\text { logical distress }\end{array}$ & 4 & 4 \\
\hline 6 & $\begin{array}{l}\text { Media usage of counselling models for Semar counsellors to improve the } \\
\text { self-esteem of vocational high school students who experience psychologi- } \\
\text { cal distress }\end{array}$ & 4 & 4 \\
\hline 7 & $\begin{array}{l}\text { The use of techniques in counselling models to improve the self-esteem of } \\
\text { vocational high school students who experience psychological distress }\end{array}$ & 4 & 4 \\
\hline 8 & $\begin{array}{l}\text { The use of procedures in the counselling model for the Semar counsellor to } \\
\text { improve the self-esteem of vocational high school students who have psy- } \\
\text { chological distress }\end{array}$ & 3 & 4 \\
\hline 9 & $\begin{array}{l}\text { The use of student duties arranged in counselling models for Semar counsel- } \\
\text { lors to improve the self-esteem of vocational high school students who } \\
\text { experienced psychological distress }\end{array}$ & 3 & 4 \\
\hline 10 & $\begin{array}{l}\text { The use of evaluation to measure the self-esteem of vocational high school } \\
\text { students experiencing psychological distress }\end{array}$ & 4 & 4 \\
\hline & Total Score & 36 & 40 \\
\hline
\end{tabular}

Based on the quantitative results, the expert on indigenous counselling gave a total score of 37 for implementation with the category of Very Appropriate, whereas the expert on Javanese culture gave a total score of 28 with the corresponding category Appropriate. Scores from both experts show that the emotionally managing skills training guide meets the criteria of implementation. The implementation guidance is also clarified through interviews with each expert. The interview results also confirm the implementation of the guidelines. Table 4 shows the expert test results for implementation.

Based on the total score and category on each aspect given by the Javanese cultural expert and the indigenous counselling expert, the Semar counselling model to improve the self-esteem of vocational high school students who experience psychological distress meets the criteria for each aspect

- Accuracy in formulating and describing the purpose and analysis of media

- Usefulness in how much benefit the Semar counselling model provides to improve the self-esteem of vocational high school students who experience psychological distress

- The implementation in terms of conformity. 
Table 4. Expert test results for implementation

\begin{tabular}{|c|l|c|c|}
\hline No & \multicolumn{1}{|c|}{ Item Statement } & $\begin{array}{c}\text { Javanese } \\
\text { Cultural } \\
\text { Expert }\end{array}$ & $\begin{array}{c}\text { Indigenous } \\
\text { Counselling } \\
\text { Expert }\end{array}$ \\
\hline 1 & $\begin{array}{l}\text { The appropriateness of the Semar counselling guide with the Semar Counsel- } \\
\text { ling Model to Improve the Self-Esteem of Vocational High School Students } \\
\text { Who Experience Psychological Distress }\end{array}$ & 3 & 4 \\
\hline 2 & $\begin{array}{l}\text { The appropriateness of the Semar counselling guide to help counsellors } \\
\text { improve the self-esteem of vocational high school students who experience } \\
\text { psychological distress }\end{array}$ & 3 & 4 \\
\hline 3 & The suitability of the student activity book design & 3 & 4 \\
\hline 4 & The appropriateness of student activity books & 3 & 4 \\
\hline 5 & $\begin{array}{l}\text { The appropriateness of the material provided in the Semar counselling model } \\
\text { guide to improve the self-esteem of vocational high school students who } \\
\text { experience psychological distress }\end{array}$ & 3 & 4 \\
\hline 6 & $\begin{array}{l}\text { The appropriateness of media used to increase the self-esteem of vocational } \\
\text { high school students who have psychological distress }\end{array}$ & 3 & 4 \\
\hline 7 & $\begin{array}{l}\text { The appropriateness of Semar counselling models used to improve the self- } \\
\text { esteem of vocational high school students who experience psychological } \\
\text { distress }\end{array}$ & 3 & 3 \\
\hline 8 & $\begin{array}{l}\text { The appropriateness of the techniques used to improve the self-esteem of } \\
\text { vocational high school students who experience psychological distress }\end{array}$ & 3 & 3 \\
\hline 9 & $\begin{array}{l}\text { The appropriateness of planned time allocation in improving the self-esteem } \\
\text { of vocational high school students who have psychological distress }\end{array}$ & 3 & 4 \\
\hline 10 & $\begin{array}{l}\text { The appropriateness of model evaluation of Semar counselling to improve the } \\
\text { self-esteem of vocational high school students who have psychological dis- } \\
\text { tress }\end{array}$ & 3 & 3 \\
\hline & \multicolumn{1}{|c|}{ Total Score } & $\mathbf{3 2}$ & $\mathbf{3 7}$ \\
\hline
\end{tabular}

\subsection{Individual test results (Counsellor)}

The design of small group trials (counsellors) is intended to test the Semar Counselling Model used to establish acceptability. The goal is to determine the practical deficiencies in the model. The user's subject consists of two school counsellors. The data collection instrument used in the form of an assessment scale refers to the Standards for the Evaluation of Educational Programs, Projects and Materials, in accordance with aspects of accuracy, usefulness and implementation.

Based on the quantitative results of the small group test (counsellor), a total score of 31 is given for accuracy with the category Very Accurate by both counsellors 1 and 2. Scores from both counsellors showed that the model meets the criteria of accuracy.

Based on the quantitative results of the small group test (counsellor) for usability, a total score of 35 with the category Very Useful (counsellor 1) and a total score of 31 with the category Very Useful (counsellor 2) are given. Scores from both counsellors showed that the model fulfils the usability criteria.

Based on the quantitative results of small group test (counsellor) for implementation, a total score of 39 with the category Very Appropriate (counsellor 1) and a total score of 36 with the category Very Appropriate (counsellor 2) are given. Scores from both counsellors showed that the model meets the criteria of implementation. 
Based on the total scores and categories given for each aspect by counsellors 1 and 2, we can conclude that the Semar counselling model meets the acceptance criteria as follows:

- Accuracy in formulating and describing the purpose and media analysis

- Usefulness in how much benefit the model provides for counsellors and students

- Implementation as shown in its suitability.

\subsection{Limitation of field test results}

After the initial field test (expert test), individual test (counsellor) and model revision, the field implementation test was conducted. This includes an analysis of the model using pretest and posttest control group design, Wilcoxon Signed Rank Test data analysis and two independent Mann-Whitney U Sample Tests.

For the field implementation test, 10 research subjects were divided into two groups: one experimental group and one control group. The experimental group used the Semar counselling model, while the control group used behavioural counselling. The field test data comprised a scoring scale developed by researchers based on the concept of Coopersmith's self-esteem theory (1967) using the following aspects:

- Power

- Significance

- Virtue

- Competence

The self-esteem instrument consists of 51 items with the following scoring criteria:

- High criterion with an interval score of 165-204

- Moderate criterion with an interval score of 127-165

- Low criterion with an interval score of 89-127

- Very low criterion with an interval score of 51-89

Tables 5 and 6 show a comparison of the pretest and posttest results in the experimental group and the control group, respectively

Table 5. Pretest and posttest results of the experimental group

\begin{tabular}{|l|c|l|c|l|c|}
\hline \multicolumn{1}{|c|}{ Counsellee } & Pretest & \multicolumn{1}{c|}{ Criteria } & Posttest & Criteria & Improvement \\
\hline IM & 98 & Low & 145 & Medium & 47 \\
\hline ADS & 102 & Low & 176 & High & 74 \\
\hline MU & 88 & Very Low & 152 & Medium & 64 \\
\hline FA & 99 & Low & 169 & High & 70 \\
\hline HI & 86 & Very Low & 138 & Medium & 52 \\
\hline
\end{tabular}


Table 6. Pretest and posttest results of the control group

\begin{tabular}{|l|l|l|l|l|l|}
\hline \multicolumn{1}{|c|}{ Counsellee } & \multicolumn{1}{|c|}{ Pretest } & \multicolumn{1}{c|}{ Criteria } & \multicolumn{1}{c|}{ Posttest } & \multicolumn{1}{c|}{ Criteria } & \multicolumn{1}{c|}{ Improvement } \\
\hline AQ & 124 & Low & 128 & Medium & 4 \\
\hline DS & 98 & Low & 117 & Low & 19 \\
\hline SA & 121 & Low & 121 & Low & 0 \\
\hline ADP & 122 & Low & 124 & Low & 2 \\
\hline NS & 125 & Low & 124 & Low & -1 \\
\hline
\end{tabular}

The result of the Wilcoxon Signed Rank Test analysis showed the average pretest score of the experimental group was 94.60 and the posttest average was 156.00 , with a minimum pretest value of 86.00 and a minimum posttest value of 138.00 . The maximum pretest score was 102.00 and the maximum posttest score was 138.00 . In other words, the value of Asymp. Sig. (2-tailed) is smaller than 0.05 , signifying an increase in self-esteem score of vocational students who experienced psychological distress in the experimental group. Furthermore, the Wilcoxon Signed Rank Test was used in the pretest average control group of 118.00 and the posttest average of 122.80; the minimum pretest value is 98.00 and the minimum posttest value is 117.00 , while the maximum pretest value is 125.00 and the maximum posttest value is 128.00 . In the statistics test, the known asymp value. sig. (2-tailed) was greater than 0.05 , indicating an increase in self-esteem score of vocational high school students who experienced posttest psychological distress in the control group.

Based on the result of the Wilcoxon Signed Rank Test of each group, an analysis was conducted by using two independent Mann-Whitney U Sample Tests, with the aim of comparing the significant difference of self-esteem level of vocational high school students experiencing psychological distress from two free samples from the same population before and after the treatment. The results of the two independent Mann-Whitney U Sample Tests for the experimental group and control group are presented below.

From the output rank above, the mean posttest in the experimental group is 8.00 , greater than that in the control group at 3.00. On the output test statistics, the obtained value of $Z$ hits -2.611 and the number of Asymp. Sig. (2-tailed) is 0.009 (0.009 $<0.05)$. The analysis result of the two independent Mann-Whitney U Sample Tests reveals a significant score difference between the experimental group and the control group at the end of the posttest, wherein the increase in the experimental group score is more significant than that in the control group score. Thus, the Semar counselling model is more effective for improving the self-esteem of vocational high school students who experience psychological distress.

The Semar counselling model to improve the self-esteem of vocational high school students who experience psychological distress is considered to be very appropriate because it uses the Gerald Corey framework, which includes

- Human nature

- Healthy and problematic person

- Counselling purpose

- Counselling relationship 
- Counselling techniques

- Counselling stages [34]

The results of the current study support the statement of Collins \& Arthur [41] that users of counselling services should be aware of their own cultural heritage in counselling services. Collins and Arthur's revelation was confirmed by Wolfgang [42], who states that a counsellor should be able to incorporate cultural issues in his counselling practice.

The Semar Counselling Model Guide has been systematically rigorous by having the following:

- General training objectives

- Training specific objectives

- Training strategies

- Training time allocations

- Training procedures

- Evaluation sheets

The results of the assessment in the test phase or product validation show that the Semar counselling model is very clear in accordance with the needs of learners. This finding is in line with the opinion of Borg \& Gall [36], who state that adjusting the needs of learners is important for the accuracy of learning.

In general, based on expert test and individual testing (counsellor), the Semar counselling model fulfils the aspect of acceptance. This is in accordance with the Standards for the Evaluation of Educational Programs, Project and Materials book developed by The Joint Committee on Standards for Educational Evaluations [40], which states that product development must meet the criteria of acceptance and standard development, including accuracy, usability and implementation. The appropriateness with the norms of society is not used such that aspects of usability, accuracy and implementation can already represent the appropriateness of the Semar counselling model to improve the self-esteem of vocational high school students who experience psychological distress. Thus, the development of the Semar counselling model to improve the self-esteem of vocational high school students who experience psychological distress meets the Standards for the Evaluation of Educational Programs, Project and Materials developed by the Joint Committee on Standards for Educational Evaluations [40].

\section{Conclusion}

The essence that we can extract from the description of exposure in the future is the effort to develop the Semar counselling model to improve the self-esteem of vocational high school students who experience psychological distress. This research is a new breakthrough for fostering the development of a counselling model based on Indonesian cultural thinking base, especially the Semar wayang culture. 
The research is conducted to produce a Semar counselling model and guidance to improve the self-esteem of vocational high school students who experience psychological distress. It fulfils the aspect of acceptance and guidance result, which consists of two products: guidance counsellor and student guide. The models and guidelines are used to provide preventive services in the form of individual or group counselling for students in need of achieving increased self-esteem.

\section{Acknowledgement}

The authors are grateful to Lembaga Pengelola Dana Pendidikan (LPDP) Indonesia for giving them the opportunity to conduct doctoral studies through the Bea Siswa Unggulan Dosen Indonesia Dalam Negeri (BUDI-DN) in 2016.

\section{References}

[1] Depdiknas. Tahun 2013 Tentang Standar Kompetensi Lulusan Pendidikan Dasar dan Menengah. Peraturan Menteri Pendidikan dan Kebudayaan No 81 Tahun 2013 tentang Pendirian Satuan Pendidikan Norformal. https://doi.org/10.31227/osf.io/6tjgx

[2] Depdiknas. Tahun 2015 tentang Kriteria Kelulusan Peserta Didik. Penyelenggaraan Ujian Nasional, Dan Penyelenggaraan Ujian Sekolah/Madrasah/Pendidikan Kesetaraan Pada SMP/MTs Atau Yang Sederajat Dan SMA/MA/SMK Atau Yang Sederajat. https://doi.org/10.31227/osf.io/6tigx

[3] Mahfud, A., Jafar, M., \& Sunawan, S. (2017). Dampak Konseling Kelompok Cognitive Behavior Therapy dengan Teknik Stress Inoculation Training terhadap Toleransi Distres Akademik melalui Hardiness. Jurnal Bimbingan Konseling, 6(1), 94-100. https://doi.org/10.12928/psikopedagogia.v5i1.4489

[4] Wulandari, K. R. (2015). Anomali Penerapan Konsep Fullday School: Studi Tentang Tingkat Stres Siswa Fullday School Di Smp Islamic Qon Gresik (Doctoral dissertation, UIN Sunan Ampel Surabaya).

[5] Yusof R., Muda T. E. A. T., \& Ishak N. M. (2016). Relationship between emotional intelligence and job satisfaction among school counseling head teachers. IOSR Journal Of Humanities And Social Science, 21, 5 (3), 61-68.

[6] Santrock, J. W. (2008). The self, identity, and personality. A topical approach to life-span development, 411-412.

[7] Misra, R., \& Castillo, L. G. (2004). Academic stress among college students: Comparison of American and international students. International Journal of Stress Management, 11(2), 132-148. https://doi.org/10.1037/1072-5245.11.2.132

[8] Lazarus, R. S. (1999). Hope: An emotion and a vital coping resource against despair. Social Research, 653-678.

[9] Miller, R. J., Sutherland, A. G., Hutchison, J. D., \& Alexander, D. A. (2001). C-reactive protein and interleukin 6 receptor in post-traumatic stress disorder: A pilot study. Cytokine, 13(4), 253-255. https://doi.org/10.1006/cyto.2000.0825 .

[10] Jaffar, A., Hizlinda T, Siti Fatimah S., Mohd Muhaimin A, Chai S.Y. Sahrina W. \& Teo B.H. (2014). Psychological disorders and help seeking behaviour among Malaysian medical students in their clinical years. Med \& Helath, 9(2), 114-123. 
[11] Shamsuddin K, Fadzil F, Ismail W. S. W., Shah S. A., Omar K., Muhammad N. A., Jaffar A., Ismail A. \& Mahadevan R. (2013). Correlates of depression, anxiety and stress among Malaysia university students. Asia Journal Psychiatry, 6, 318-323. https://doi.org/10.1 016/j.ajp.2013.01.014

[12] Wahab S., Rahman F. N. A., Hasan W. M. H. W., Zamani I. Z., Arbaiei N. C., Khor, S. L. \& Nawi A. M. (2013). Stressors in secondary boarding school students: Association with stress, anxiety and depressive symptoms. Asia-Pacific Psychiatry, 5, 82-89. https://doi.org/10.1111/appy.12067

[13] Kim, E., Newton, F. B., Downey, R. G., \& Benton, S. L. (2010). Personal factors impacting college student success: Constructing College Learning Effectiveness Inventory (CLEI). College Student Journal, 44(1).

[14] Habsy, B. A. (2017). Model Konseling Kelompok Cognitive Behavior Untuk Meningkatkan Self Esteem Siswa SMK. Perspektif Ilmu Pendidikan, 31(1), 21-35. https://doi.org/10.21009/PIP.311.4

[15] Bos, A. E., Muris, P., Mulkens, S., \& Schaalma, H. P. (2006). Changing self-esteem in children and adolescents: A roadmap for future interventions. Netherlands Journal of Psychology, 62(1), 26-33. https://doi.org/10.1007/BF03061048.

[16] Lee, G.M., Johari K. S. K., Mahmud Z, \& Jamaludin L. (2018). The impact of sandtray therapy in group counseling towards children's self-esteem. International Journal of Academic Research in Business and Sciences, 8 (4), 1045-1057.

[17] Ismail, M., Aziz, F. H., AB, M. F., Ismail, M. F., \& PM, A. S. (2017). The Relationship between Self-Efficacy and GPA Grade Scores of Students. International Journal of Applied Psychology, 7(2), 44-47.

[18] Twenge, J. M., \& Campbell, W. K. (2002). Self-esteem and socioeconomic status: A metaanalytic review. Personality and Social Psychology Review, 6(1), 59-71. https://doi.org/10.1207/S15327957PSPR0601_3.

[19] Coopersmith, S. (1967). Coopersmith self-esteem inventory form A. Self-Esteem Institute. https://doi.org/10.1037/t42104-000

[20] McKay, M., \& Fanning, P. (1987). Self-Esteem. New York: St

[21] Akos, P \& Galassi, J. P. (2004). Developmental Advocacy: Twenty-First Century School Counseling. Journal of Counseling and Development, 82(2), 146-157. https://doi.org/10.10 02/j.1556-6678.2004.tb00296.x .

[22] Leach, M. M., Aten, J. D., Boyer, M. C., Strain, J. D., \& Bradshaw, A. K. (2010). Developing therapist self-awareness and knowledge. Culture and the therapeutic process: A guide for mental health professionals, 13-36.

[23] Dahlan, D. (2005). Pendidikan dan Konseling di Era Global. Dalam Perspektif Prof. Dr. M. Djawat Dahlan.

[24] Hidayah, N. \& Ramli, M. 2017. Need of Cognitive-Behavior Counseling Model Based on Local Wisdom to Improve Meaning of life of Madurese Culture Junior High School Students. Advances in Social Science, Education and Humanities Research, volume 128. Atlantis Press. https://doi.org/10.2991/icet-17.2017.53

[25] Habsy, B. A., Hidayah, N., \& Lasan, B. B. (2017). A Literature Review of Indonesian Life Concept Linuwih Based on the Teachings of Adiluhung Raden Mas Panji Sosrokartono https://doi.org/10.2991/icet-17.2017.10

[26] Prayitno, (1998). Konseling Pancawaskita: Kerangka Konseling Eklektik. Padang: BK-FIP Universitas Negeri Padang, https://doi.org/10.30596/bibliocouns.vli1.1941

[27] Suseno, F. (2009). Menjadi Manusia Belajar dari Aristolteles. Kanisius.

[28] Endraswara, S. (2016). Berpikir positif orang Jawa. Narasi.

[29] Suseno, Franz Magnis. "Etika Jawa." Jakarta: Gramedia (2001). 
[30] Izzati, A. (2017). Nilai-nilai Konstruk Harmoni Perspektif Tokoh Wayang Semar. Fikrah, 4(2), 261-275. https://doi.org/10.21043/fikrah.v4i2.1631.

[31] Purwadi. (2014). Mengkaji nilai-nilai luhur semar. Karwa Publisher Yogyakarta.

[32] Hermawan, D. (2013). Semar dan kentut kesayangannya.

[33] Haq, M. Z. (2009). Tasawuf Semar hingga Bagong: simbol, makna, dan ajaran makrifat dalam panakawan. Kreasi Wacana.

[34] Corey, G. (2015). Theory and practice of counseling and psychotherapy. Nelson Education.

[35] Habsy, B. A. (2017). Semar puppet counseling model. COUNS-EDU: The International Journal of Counseling and Education, 2(1), 19-24. https://doi.org/10.23916/002017024410

[36] Borg, W. R., \& Gall, M. D. (1983). Instructor's Manual for Educational Research: To Accompany Educational Research: an Introduction. Longman.

[37] Gall, M. D., Gall, J. P., \& Borg, W. R. (2003). Nonexperimental research: Correlational designs. Education research: An introduction (7th ed., pp. 319-364). New York.

[38] Dwiyogo, W. D. (2004). Konsep penelitian dan pengembangan. Pusat Kajian Kebijakan Olahraga LEMLIT UM.

[39] Sukmadinata, S. (2009). Nana, Metode Penelitian Pendidikan, Bandung: PT. Remaja Rosdakarya.

[40] The Joint Committee on Taxation. (1981). General Explanation of the Economic Recovery Tax Act of 1981.

[41] Collins, S., Arthur, N., \& Wong Wylie, G. (2010). Enhancing reflective practice in multicultural counseling through cultural auditing. Journal of Counseling and Development, 88(3), 340-347. https://doi.org/10.1002/j.1556-6678.2010.tb00031.x

[42] Wolfgang, A. A. R. O. N. (1985). The function and importance of nonverbal behavior in intercultural counseling. Handbook of cross-cultural counseling and therapy, 99-105.

\section{$7 \quad$ Authors}

Bakhrudin All Habsy, M.Pd. Authors was born in east java, Indonesia in 1987. Author received a Bachelor of Education degree in Counseling and Guidence in 2010 from Universitas Negeri Surabaya, Master's degree in Counseling and Guidence from Universitas Negeri Malang, Indonesia, in 2014. He is currently pursuing a doctorate degree in Counseling and Guidence at Universitas Negeri Malang, Indonesia. From 2014 active as a researcher and lecturer at Universitas Darul Ulum. His research interests include Counseling, Cognitive Behavior Approach, Group Counseling and Group Guidance, Qualitative Approach in Counseling, Cultural Approach in Counseling, and etc. Author is a member of The Indonesian Counselors Association from 2012. He is currently active as a team of editors and reviewers in several Indonesian journals.

Prof. Dr. Nur Hidayah, M.Pd. Author was born in east java, Indonesia in 1959. Author recieved a Bachelor of Education degree in Counseling and Guidence in 1982, Master's degree in Counseling and Guidence in 1991 from IKIP Malang, and Doctoral degree in Counseling and Guidence in Universitas Negeri Malang, Indonesia, in 2009. Since 2015, he is a professor in Counseling and Guidence at Universitas Negeri Malang, Indonesia. From 1984 active as a researcher and lecturer at Universitas Negeri Malang. His research interests include Counseling, Cyber Counseling, Cognitive Behavior Approach, Group Counseling, Cultural Approach in Counseling, Evaluation 
And Supervision Counseling and Guidence, Non-Test Technical Assessment, Educational Psychology, and etc.

Dr. Blasius Boli Lasan, M.Pd. Author was born in Larantuka, Indonesia in 1957. Author recieved a Bachelor of Education degree in Counseling and Guidence in 1982, Master's degree in Counseling and Guidence in 1997 from IKIP Malang, and Doctoral degree in Counseling and Guidence in Universitas Negeri Malang, Indonesia, in 2009. From 1986 active as a researcher and lecturer at Universitas Negeri Malang. His research interests include Counseling, Cultural Approach in Counseling, Qualitative Approach In Counseling, Philosophy Counseling, Career Guidance, and etc.

Dr. Muslihati, S.Ag, M.Pd. Author was born in east java, Indonesia in 1976. Author recieved a Master's degree in Counseling and Guidence in 2003 and Doctoral degree in Counseling and Guidence in Universitas Negeri Malang, Indonesia, in 2012. Active as a researcher and lecturer at Universitas Negeri Malang. His research interests include Counseling, Qualitative Approach in Counseling, Cultural Approach in Counseling.

Ahmad Fudholi, Ph.D, M.Sc, S.Si. Author has published more than 120 peerreviewed papers, of which 35 papers are in the WoS index $(25 \mathrm{Q} 1$, impact factor more than 4) and more than 80 papers are in the Scopus index. He has published more than 80 papers in international conferences. He has a total citations of 1225 and a h-index of 17 in Scopus (Author ID: 57195432490). He has a total citations of 1684 and a hindex of 21 in Google Scholar. He has been appointed as reviewer of high-impact (Q1) journals. He has also been appointed as editor of journals. He has received several international awards. He owns one patent and two copyrights.

Article submitted 2019-01-28. Resubmitted 2019-05-02. Final acceptance 2019-05-02. Final version published as submitted by the authors. 